
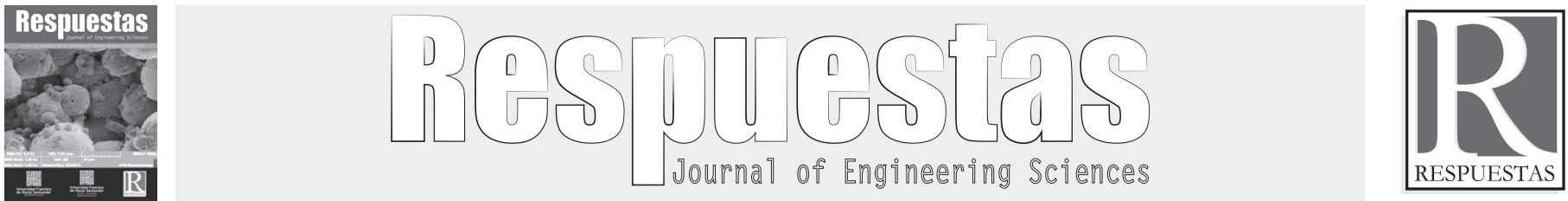

Original Article

https://doi.org/10.22463/0122820X.1680

\title{
Physical-ceramic characterization of clays used in the manufacture of mansory products for construction
}

\section{Caracterización físico-cerámica de arcillas utilizadas en la fabricación de productos de mampostería para la construcción}

\section{Ricardo Andrés García-León ${ }^{1 *}$, Eder Norberto Flórez-Solano², Carlos Acevedo-Peñaloza ${ }^{3}$}

${ }^{1 *}$ Magíster en Ingeniería Industrial, ragarcial@ufpso.edu.co, Orcid: 0000-0002-2734-1425, Universidad Francisco de Paula Santander Ocaña, Ocaña, Colombia. ${ }_{2}^{2}$ Magister en Ingeniería Mecánica, enflorezs@ufpso.edu.co, Orcid: 0000-0003-2527-0413, Universidad Francisco de Paula Santander Ocaña, Ocaña, Colombia. ${ }^{3}$ Doctor en Ingeniería Mecánica, carloshumbertoap@ufps.edu.co, Orcid: 0000-0002-5049-8754, Universidad Francisco de Paula Santander, Cúcuta, Colombia.

How to cite: R.A. García-León, E.N. Flórez-Solano and C.H. Acevedo-Peñaloza, "Physical-ceramic characterization of clays used in the manufacture of mansory products for construction", Respuestas, vol. 23, no. 2, pp. 13-25, 2018.

Received on January 27, 2018; Approved on June 03, 2018.

\begin{tabular}{ll}
\hline KBSTRACT \\
\hline Keywords: & Nowadays, in Colombia, specifically in the north-eastern, in Santander region, the process of mixing the \\
Brick & ceramic paste used to manufacture masonry products for construction (H- 10 bricks, tiles, roof tiles, etc.) is \\
Ceramic & done manually. For this reason, approximately $70 \%$ of the companies do not possess the technological tools \\
DOE & which facilitate the prediction of the behavior of the raw material (clay). The main objective of this research is \\
H-10 bricks & to formulate mixtures at a laboratory-level in order to verify the physical properties of ceramic raw materials \\
Hydrometry & used by a company which was takenas a sample. The research development was carried out through the \\
Mixing & execution of tests and laboratory analysis, taking into account the formulation of mixtures with the help \\
& of Statgraphics Centurion XV software in order to obtain combinations of raw materials according to the \\
& requirements of the current standard techniques. The results demonstrate the importance of using statistical \\
& programs for the improvement of systems and processes, predicting the behavior of raw materials as well \\
& as conducting pilot tests, taking into account the laboratory analyses in the ceramic industry. Furthermore \\
& that the mixture combinations obtained have the necessary parameters to meet the current standards such as \\
& resistance and absorption, which will optimize the economic and physical resources of the company, as well \\
& as the quality of the final product.
\end{tabular}

\section{RESUMEN}

\section{Palabras clave:}

Ladrillera

Cerámica

DOE

Bloques H-10

Hidrometría

Mezclado
Actualmente en Colombia específicamente en la región nortesantandereana, el proceso de mezclado de la pasta cerámica para la fabricación de productos de mampostería para la construcción (bloques H-10, baldosas, tejas, etc.) se realiza de forma artesanal, es de esta manera que aproximadamente el $70 \%$ de las empresas no cuentan con herramientas tecnológicas que permitan la predicción del comportamiento de la materia prima (la arcilla). El principal objetivo de esta investigación fue formular mezclas a nivel laboratorio para comprobar las propiedades físico-cerámicas de la materia prima utilizada por una empresa tomada como muestra. El desarrollo de la investigación se llevó a cabo mediante la ejecución de pruebas y análisis de laboratorio teniendo en cuenta la formulación de mezclas con la ayuda el software Statgraphics Centurion $\mathrm{XV}$, con la finalidad de obtener combinaciones de materia prima acordes a los requerimientos de las normas técnicas actuales vigentes. Los resultados demuestran la importancia de la utilización de programas estadísticos para el mejoramiento de sistemas y procesos, prediciendo el comportamiento de las materias primas como también la realización de pruebas piloto teniendo en cuenta los análisis de laboratorio en la industria cerámica. Así mismo, las combinaciones de mezcla obtenidas cuentan con los parámetros necesarios de las normas actuales vigentes como resistencia y absorción, lo cual permitirá optimizar los recursos económicos y físicos de la empresa, como también la calidad del producto final.

*Corresponding author

E-mail address: ragarcial@ufpso.edu.co (Ricardo Andrés García León)

(c) $(1) \Theta$ Peer review is the responsibility of the Universidad Francisco de Paula Santander.

This is an article under the license CC BY-ND (http://creativecommons.org/licenses/by-nc-nd/4.0/). 


\section{Introduction}

There are three phases which make up the process: preparation of the ceramic paste, molding of the piece and heating. In the first phase of the preparation process, the composition and plasticity of the substance are modified by adding other clays in order to obtain a homogeneous ceramic paste. It is then molded according to the desired shape under pressure or extrusion. Once the molded piece has been obtained, it is dried while controlling the speed of water evaporation in order to avoid defects in the piece. Subsequently, the piece is sintered, i.e. it

undergoes the heating process in order to reduce porosity and increase density as well as mechanical resistanc [1]-[6].

According to production capacity and technological development, the brick-making industries have been classified into two main categories: tilework and small, medium or large brick-molders [7]. However, these companies generally maintain the productive process as can be seen in figure 1 . or alumina $\left(\mathrm{Al}_{2} \mathrm{O}_{3}\right)$ which is used as flux and the third is silica $\left(\mathrm{SiO}_{2}\right)$ which is used as a filler and stabiliser material [8], [9]. These compositions are determined by the chemical composition, which is the basis of the modern classification of minerals and the approximation of the mixtures with the ternary diagrams [10]-[12], which in the case of many factories producing blocks or bricks do not take into account the proportions of each of these chemical components.

The physical-ceramic characterization is performed with the purpose of observing the behavior of the material in the drying stage, determining mainly the contraction speed of the sample at the different selected temperatures and relating the losses due to drying with the percentage of dry contraction of the specimens conformed in the laboratory [13]-[15].

Statistics is a tool commonly used in this type of research, for example in Camboya, two clay deposits were used for the development of tile formulations (Blocks) by means of the statistical design of mix
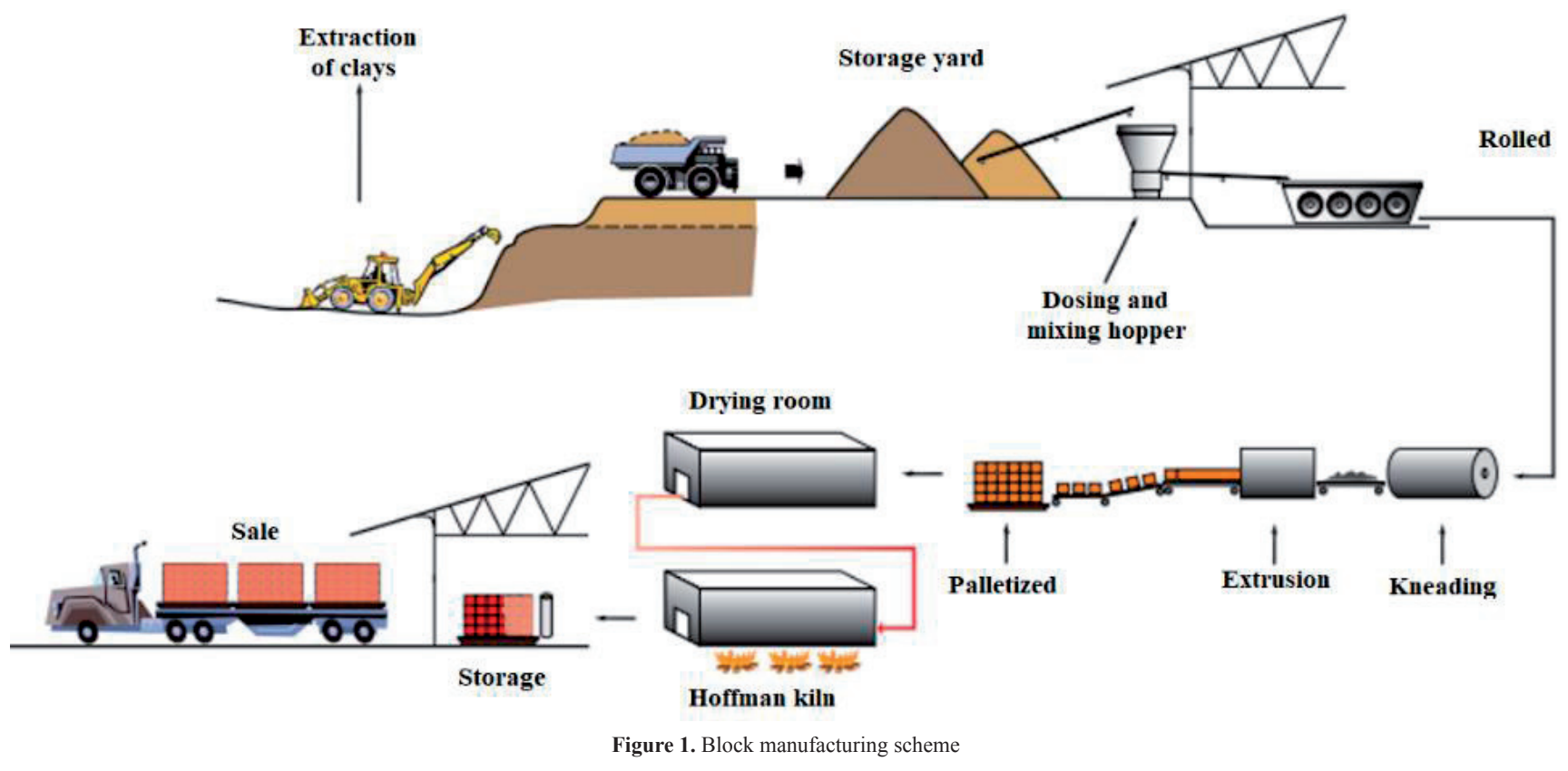

Generally, three components are used that play important roles in optimizing the performance of the final properties of blocks and ceramic materials. The first component is clay, so its plasticity facilitates the structure of the product, while the second is feldspar experiments and the adequacy of the models were confirmed in laboratory by means of experimental analyses [16]. Coronado and Segadães used the experimental mixture design (M-DoE) to define the minimum number of mixtures needed to model and 
predict technological properties (water absorption, flexural strength, open porosity, linear firing shrinkage, weight loss and bulk density) [17].

Therefore, there is an evaluation methodology using mathematical techniques and specific statistics for the design of a mixture of experiments, in which the desired properties are defined and an optimal mixture is established using a minimum number of experiments, where the development of a method is carried out that involves experiments varying the proportions of components of a product from the analysis of changes in properties [12], [18]. An important characteristic in mixture designs is that independent or controllable factors (clay paste) represent proportions of the mixture. These proportions should not be negative and are expressed as mixture fractions [19]-[23].

\section{Materials and methods}

In the development of this work a deep descriptive investigation was carried out, given that the purpose is to detail the variables involved in the preparation of the mixture for the manufacture of masonry products for construction, which consists of an experimental design to identify the effects produced by the variables studied such as the composition of clay (Sand - Loam - Clay). The type of purpose is basic given that up to the moment the results of the investigation were not implemented by the companies of the sector in the region Nortesantandereana.

On the other hand, the approach of the project was of mixed type (qualitative - quantitative), considering that from the qualitative studies of the state of art and literature concerning the topic of research in books, degree works, scientific articles and other data from reliable bibliographic sources were carried out.

On a quantitative level, as it was an experimental type of investigation, taking into account that the collection of clay samples was carried out directly in the mines of a brick kiln by means of direct observation. Likewise, from the results of the analyses obtained from the samples, the variables to be studied were determined for the planning and implementation of the experimental studies. In addition, laboratory tests were carried out in order to determine the variables that were the object of study, in order to identify those that have the greatest impact and thus design the optimal mixture in the manufacture of $\mathrm{H}-10$ blocks [24].

The extraction of the raw sample was approximately $100 \mathrm{~kg}$. which was chosen directly from the clay mines in the courtyards of the company, then it was made its subsequent crushing to obtain $5 \mathrm{~mm}$ in diameter of the particles, followed by a homogenization and quartzite where $50 \mathrm{~kg}$. were used approximately for laboratory analysis and the remaining $50 \mathrm{~kg}$ were witness sample for further experiments if necessary.

The samples were taken in a channel type, where several clay veins were selected from a mine used to obtain the mixture of ceramic material. In this stage, five samples were selected for the previous studies.

\section{Results and Discussion}

In the first step to determine the variables that are part of the composition of the clay paste, the analysis of granulometry by sieving and hydrometry was carried out to establish the percentages of sands, silts and clays from five samples that are used by the selected company, obtaining the following results:

Table I. Hydrometric data by granulometry

\begin{tabular}{|c|c|c|c|}
\hline \multirow{2}{*}{ Sample } & $\begin{array}{c}\text { \%o Sands } \\
\text { Sieve: } \mathbf{1 0 0} \mathbf{~ m m}-\mathbf{0 , 0 8} \mathbf{~ m m}\end{array}$ & $\begin{array}{c}\text { \% Silt } \\
\text { Sieve: } \mathbf{0 , 0 8} \mathbf{~ m m}-\mathbf{0 , 0 0 5} \mathbf{~ m m}\end{array}$ & $\begin{array}{c}\text { \% Clays } \\
\text { Sieve: } \mathbf{0 , 0 0 5} \mathbf{~ m m}-\mathbf{0} \mathbf{~ m m}\end{array}$ \\
\hline M1 & 58,0 & 18,0 & 24,0 \\
\hline M2 & 61,0 & 17,8 & 21,2 \\
\hline M3 & 56,3 & 38,1 & 5,9 \\
\hline M4 & 59,7 & 31,1 & 4,6 \\
\hline M5 & 58,0 & 27,0 & 15,0 \\
\hline
\end{tabular}


The data obtained in table I were plotted in the Winkler diagram with the help of the TripLop software (figure 2), where the points were located to characterize the clays taking into account the percentages of sands, silts and clays, and also to check if they are suitable for the current production carried out in the selected company [24], [25]. Also, the clay textures were identified and types of products that can be obtained [26], depending on the composition, can be identified by the area in which they are found that are soils Franco-sand-clayey, which its use is largely for the manufacture of solid bricks and perforated blocks.

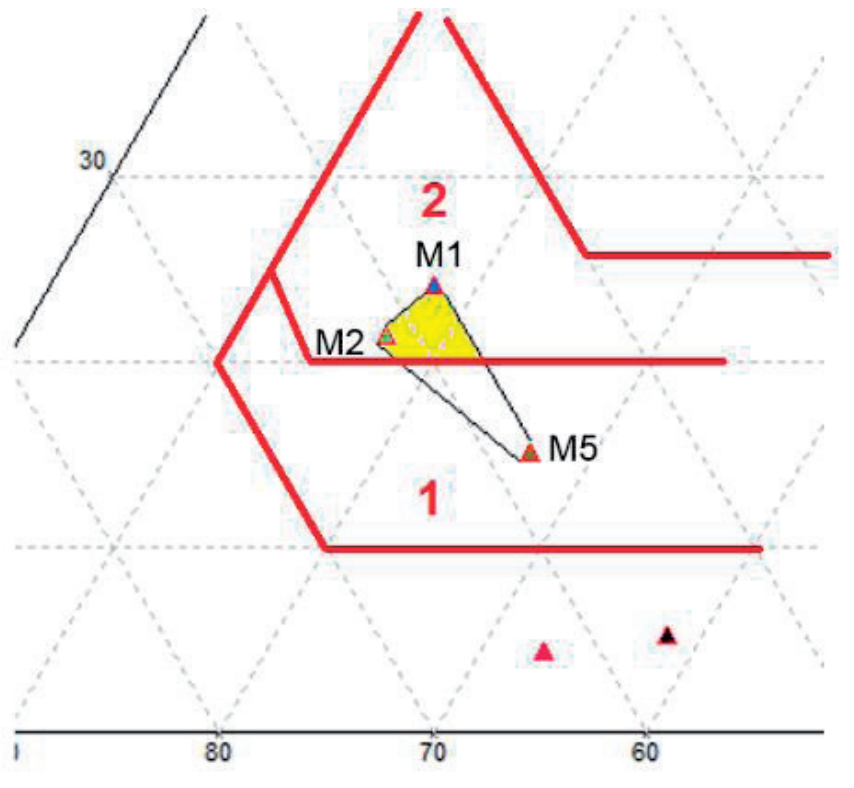

Figure 2. Possible optimum region for the clay mixture

Then, the experimental design of the mixture was carried out using the statistical software Stargraphics Centurion based on M1, M2 and M5 samples, since they are the ones that can provide a better composition of the clay paste, taking into account the following table:
Having the experimental design formulated based on the percentages of sands, silts and clays of the selected samples, the physical-ceramic characterization of the optimal mixtures (M7 and M8) was carried out in order to observe the behavior of the ceramic material in the drying stage, mainly determining the contraction speed of the sample at the different selected temperatures and relating the losses due to drying with the percentage of dry contraction of the conformed specimens [13]-[15].

As the properties of the clays are variable, the optimum region identified in figure 2 for the manufacture of $\mathrm{H}-10$ perforated blocks can be seen more broadly in table III. In addition, it was determined that a possible central point of the region determined as optimal among the selected samples (58.5\% Sand - 20.1\% Silt - 21.4\% Clay).

\begin{tabular}{|c|c|c|} 
Table III. Optimum region for the manufacture of blocks \\
\hline Component & For the samples studied & For winkler zone 2 \\
\hline Sand range (\%) & $58-61$ & $50-65$ \\
\hline Silt range (\%) & $18-23$ & $10-30$ \\
\hline Clay range (\%) & $20-24$ & $20-40$ \\
\hline
\end{tabular}

\section{Optimum blends}

Taking into account the mix design carried out, it was established that M7 and M8 mixes had percentages close to those established in zone two of the Winkler diagram, obtaining the following results illustrated in figure 3:

In order to carry out the physico-ceramic analysis, the samples selected were determined according to the proportions of the design of the experiments, taking into account the following table IV:

Table II. Software results of the experimental design

\begin{tabular}{|c|c|c|c|c|c|c|c|}
\hline Blends & Sample 1 & Sample 2 & Sample 5 & \% sand & \% silt & \% clay & Mix of clay \\
\hline M1 & 100,00 & 0,00 & 0,00 & 58,00 & 18,00 & 24,00 & Pure \\
\hline M2 & 0,00 & 100,00 & 0,00 & 61,00 & 17,00 & 21,00 & Pure \\
\hline M3 & 0,00 & 0,00 & 100,00 & 58,00 & 27,00 & 15,00 & Pure \\
\hline M4 & 50,00 & 50,00 & 0,00 & 59,50 & 18,00 & 22,50 & Combined \\
\hline M5 & 50,00 & 0,00 & 50,00 & 58,00 & 22,50 & 19,50 & Combined \\
\hline M6 & 0,00 & 50,00 & 50,00 & 59,50 & 22,50 & 18,00 & Combined \\
\hline M7 & 33,33 & 33,33 & 33,33 & 58,49 & 21,00 & 20,51 & Combined \\
\hline M8 & 66,67 & 16,67 & 16,67 & 58,00 & 20,00 & 22,00 & Combined \\
\hline M9 & 16,67 & 66,67 & 16,67 & 60,01 & 19,50 & 20,50 & Combined \\
\hline M10 & 16,67 & 16,67 & 66,67 & 58,51 & 24,00 & 17,50 & Combined \\
\hline
\end{tabular}




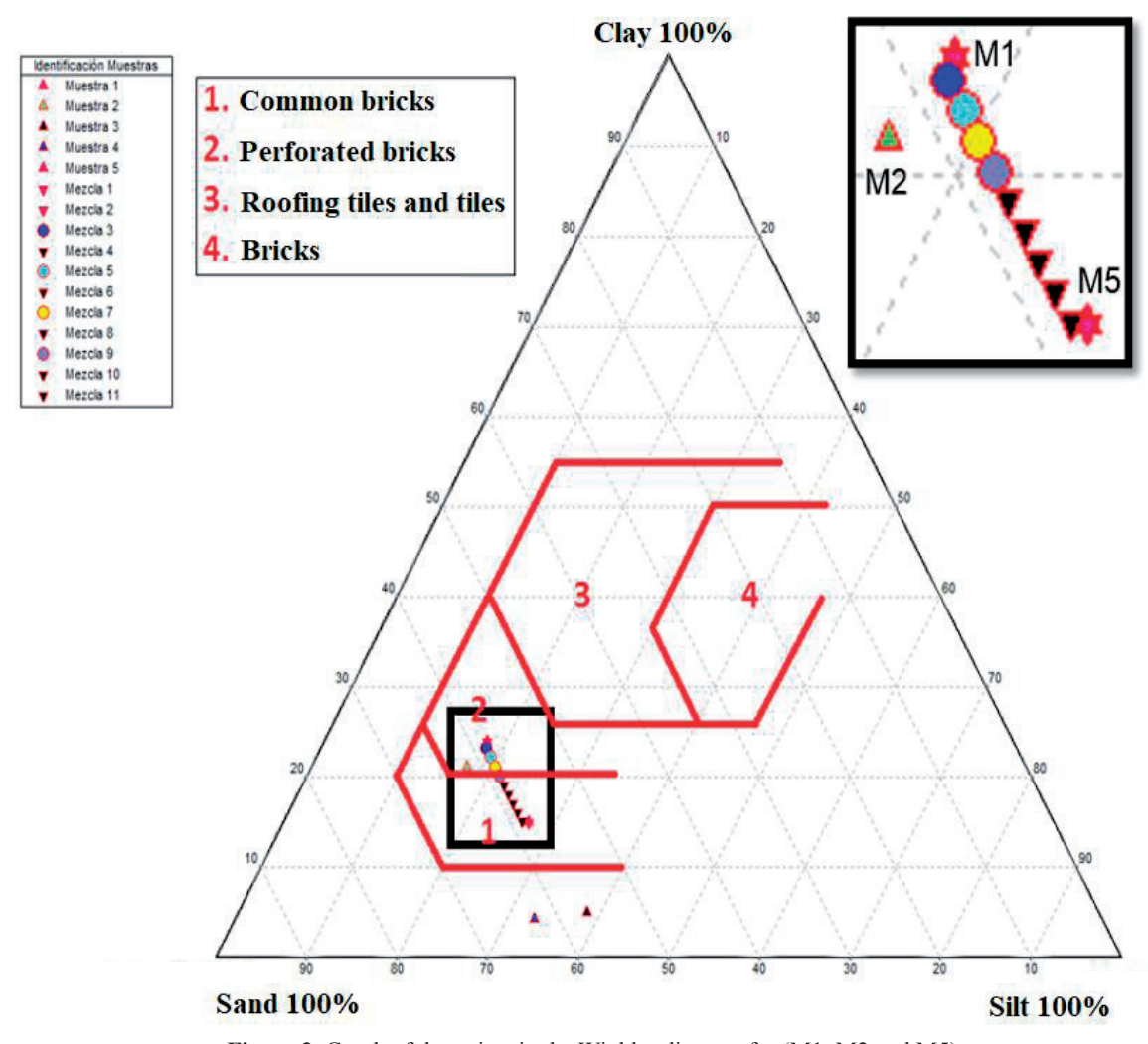

Table IV. Preparation of samples as obtained in statistical design

\begin{tabular}{|c|c|c|c|c|}
\hline Blends Samples & M1 & M2 & M5 & Total \\
\hline \multirow{2}{*}{ M7 } & 10 Kilograms & 10 Kilograms & 10 Kilograms & \multirow{2}{*}{30 Kilograms } \\
\hline & $33.33 \%$ & $33.33 \%$ & $33.33 \%$ & \\
\hline \multirow{2}{*}{ M8 } & 20 Kilograms & 5 Kilograms & 5 Kilograms & \multirow{2}{*}{30 Kilograms } \\
\hline & $66.67 \%$ & $16.66 \%$ & $16.66 \%$ & \\
\hline
\end{tabular}

\section{Physical-ceramic analysis}

At this stage of the research, specimens were formed by the extrusion process, passing through the different stages at the laboratory level, in order to simulate the industrial process of manufacturing a traditional ceramic product. The selected samples were determined according to the proportions of the design of the experiments.

\section{Retained on sieve and hydrometry}

The sieve retention and hydrometry analysis was carried out to calculate the percentages of sand, silt and clays of the selected mixtures, as well as the calculation of the plasticity index, obtaining the following results:

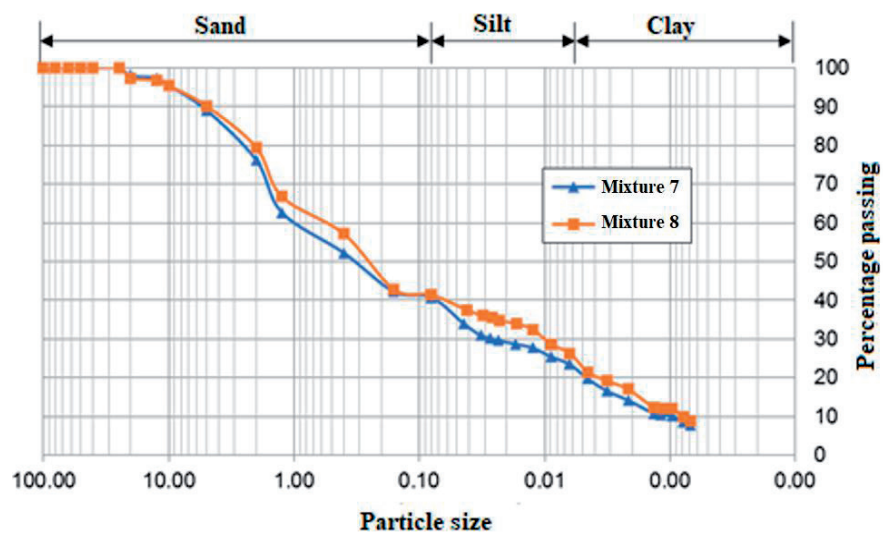

Figure 4. Sieve and Hydrometric grading of mixtures M7 and M8

From Figure 4, the following expected results were obtained as experimentally determined:

Table V. Hydrometric data by grain size for mixtures M7 and M8

\begin{tabular}{|c|c|c|c|}
\hline Blend & $\begin{array}{c}\text { \% sands } \\
\text { Sieve: } \mathbf{1 0 0} \mathbf{~ m m}- \\
\mathbf{0 , 0 8} \mathbf{~ m m}\end{array}$ & $\begin{array}{c}\text { \% silt } \\
\text { Sieve: } \mathbf{0 , 0 8} \mathbf{~ m m}- \\
\mathbf{0 , 0 0 5} \mathbf{~ m m}\end{array}$ & $\begin{array}{c}\text { \% clays } \\
\text { Sieve: } \mathbf{0 , 0 0 5} \mathbf{~ m m}- \\
\mathbf{0 ~} \mathbf{~ m m}\end{array}$ \\
\hline M7 & 58,99 & 20,93 & 20,06 \\
\hline M8 & 58,49 & 19,46 & 22,03 \\
\hline
\end{tabular}

Taking into account table $\mathrm{V}$, the mixtures belong to the soil type Franco- sand-clayey, being also in the region two for the manufacture of perforated products 
and in the ranges established for the manufacture of ceramic products.

Table VI. Calculation of soil type for mixtures M7 and M8

\begin{tabular}{|c|c|c|}
\hline Parameter & Blend M7 & Blend M8 \\
\hline Liquid Limit LL (\%) & 26,85 & 27,13 \\
\hline Plastic Limit PL (\%) & 21,21 & 21,56 \\
\hline Plasticity Index PI (\%) & 5,64 & 5,57 \\
\hline
\end{tabular}

Taking table VI into account, the values of the liquid limit and plasticity index are plotted in the Casagrande diagram (figure 5) and the extrusion prediction diagram (figure 6) to determine the percentage of water that must be applied to the ceramic paste for its conformation:Taking into account Table VI and Figures 5 and 6, clay mixtures are considered to be complex extrusions due to their low plasticity index which is also found in the CL-ML zone.

Material conformation The forming of M7 and M8 mixtures was carried out by the extrusion method, due to the fact that it is the method commonly used by companies. The following table VII shows the parameters obtained by the laboratory:

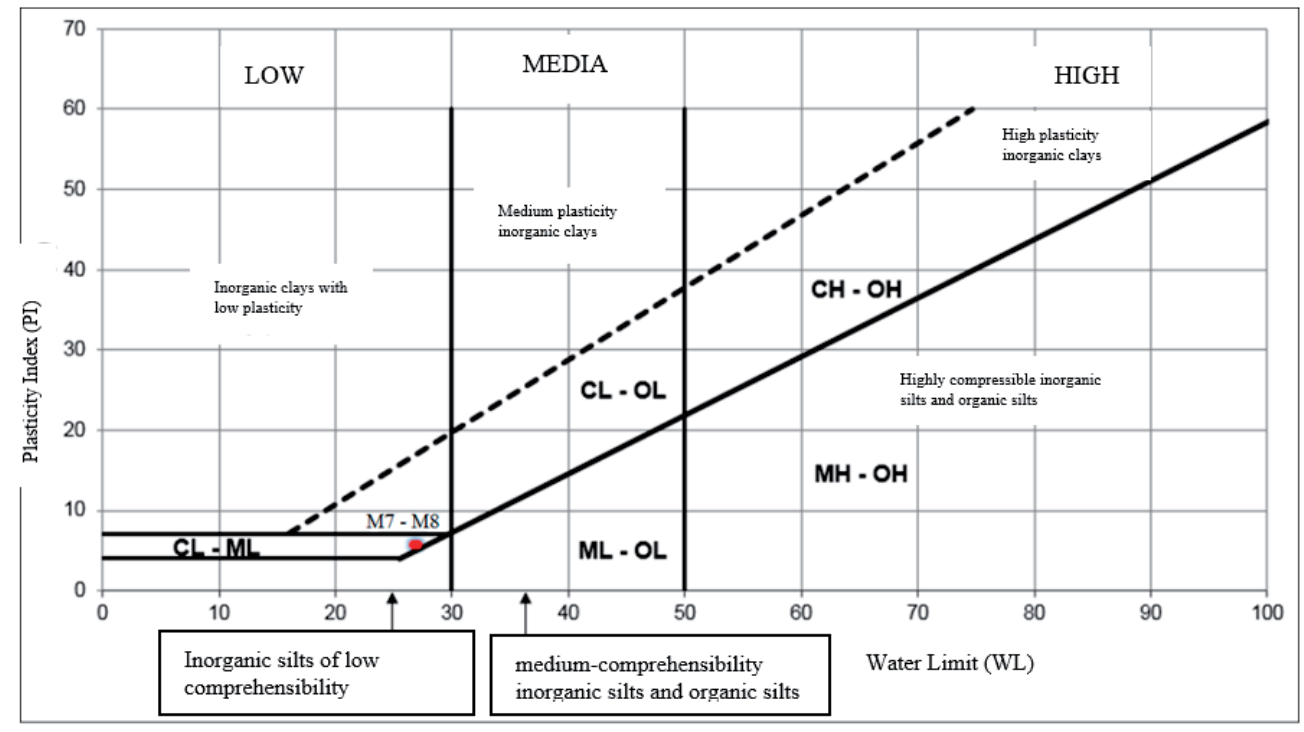

Figure 5. Plasticity in the Casagrande diagram for mixtures M7 and M8

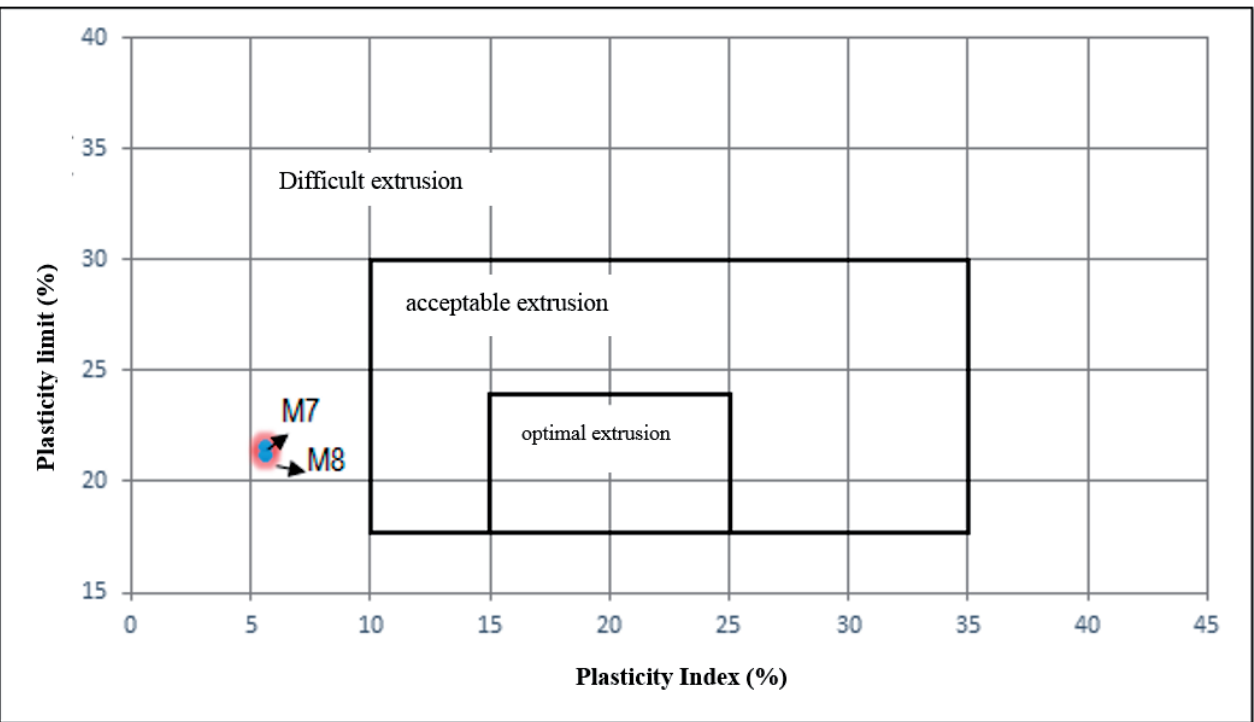

Figure 6. Prediction diagram of the extrusion and/or molding through the Atterberg Limits0 
Table VII. Condition of the mixtures for the forming

\begin{tabular}{|c|c|c|}
\hline Parameter & Value M7 & Value M8 \\
\hline Initial Humidity (\%) & 3,60 & 2,68 \\
\hline Water mass (gr) & 3871 & 3523 \\
\hline Sample mass (gr) & 15800 & 15800 \\
\hline Extrusion pressure (mmHg) & 35 & 35 \\
\hline Sand in mesh ASTM 230 (\%) & 51,57 & 53,58 \\
\hline
\end{tabular}

The plastic mass was homogenized during 12 hours, in order to obtain a good wetting. Subsequently, rectangular geometry specimens $11 \mathrm{~cm}$ long by $4 \mathrm{~cm}$ wide and $1 \mathrm{~cm}$ thick were molded. The drying was carried out during twelve hours at room temperature and then in a drying oven from $60^{\circ} \mathrm{C}\left( \pm 5^{\circ} \mathrm{C}\right)$ to $110^{\circ} \mathrm{C}$ $\left( \pm 5^{\circ} \mathrm{C}\right)$, with a heating speed of $10^{\circ} \mathrm{C} /$ hour and once this temperature was reached it was maintained during twenty-four (24) hours of drying.

\section{Linear contraction}

This analysis was carried out with the purpose of mainly determining the contraction speed of the sample at the different temperatures selected and relating the losses due to drying with the percentage of dry contraction of the specimens conformed in the laboratory.

The shrinkage was measured by difference in weight and dimensions in drying and cooking. The drying shrinkage was carried out at $110^{\circ} \mathrm{C}$ for approximately 24 hours. The following results tables VIII and IX were obtained:

Table VIII. Linear shrinkage values for the extruded specimens of the mixture M7

\begin{tabular}{|c|c|c|c|c|c|c|c|c|c|c|}
\hline \multirow{2}{*}{$\begin{array}{c}\text { Test } \\
\text { piece }\end{array}$} & \multirow{2}{*}{$\begin{array}{c}\text { Temperature } \\
\left({ }^{\circ} \mathrm{C}\right)\end{array}$} & \multicolumn{2}{|c|}{ Dry condition } & \multicolumn{2}{|c|}{ Cooked condition } & \multicolumn{2}{|c|}{ Contraction } & \multicolumn{2}{|c|}{ Mass losses } & \multirow{2}{*}{ Water absorption (\%) } \\
\hline & & Length (mm) & $\begin{array}{c}\text { Mass } \\
\text { (g) }\end{array}$ & Length (mm) & $\begin{array}{c}\text { Mass } \\
(\mathrm{g})\end{array}$ & $\begin{array}{l}\text { Dry } \\
(\%)\end{array}$ & $\begin{array}{c}\text { Cooked } \\
(\%)\end{array}$ & $\operatorname{Dry}(\%)$ & Cooked(\%) & \\
\hline 1 & 1050 & 112,18 & 70,58 & 112,03 & 67,47 & \multirow{6}{*}{6,059} & 0,138 & \multirow{6}{*}{26,284} & 4,406 & 19,505 \\
\hline 2 & 1000 & 110,80 & 70,59 & 111,67 & 67,23 & & 0,112 & & 4,760 & 19,569 \\
\hline 3 & 950 & 110,62 & 70,68 & 110,57 & 67,59 & & 0,045 & & 4,372 & 19,611 \\
\hline 4 & 900 & 111,69 & 70,73 & 111,89 & 67,7 & & $-0,179$ & & 4,277 & 19,764 \\
\hline 5 & 850 & 112,14 & 71,49 & 112,63 & 68,6 & & $-0,437$ & & 4,043 & 19,913 \\
\hline 6 & 800 & 113,19 & 71,09 & 113,8 & 68,5 & & $-0,539$ & & 3,636 & 20,117 \\
\hline
\end{tabular}

\begin{tabular}{|c|c|c|c|c|c|c|c|c|c|c|}
\hline \multirow{2}{*}{$\begin{array}{l}\text { Test } \\
\text { piece }\end{array}$} & \multirow{2}{*}{$\begin{array}{c}\text { Tempera- } \\
\text { ture } \\
\left({ }^{\circ} \mathrm{C}\right)\end{array}$} & \multicolumn{2}{|c|}{ Dry condition } & \multicolumn{2}{|c|}{ Cooked condition } & \multicolumn{2}{|c|}{ Contraction } & \multicolumn{2}{|c|}{ Mass losses } & \multirow{2}{*}{ Water absorption (\%) } \\
\hline & & $\begin{array}{c}\text { Length } \\
(\mathrm{mm})\end{array}$ & Mass (g) & $\begin{array}{c}\text { Length } \\
(\mathrm{mm})\end{array}$ & Mass (g) & $\begin{array}{l}\text { Dry } \\
(\%)\end{array}$ & $\begin{array}{c}\text { Cooked } \\
(\%)\end{array}$ & $\operatorname{Dry}(\%)$ & Cooked(\%) & \\
\hline 1 & 1050 & 112,52 & 72,27 & 113,47 & 69,03 & \multirow{6}{*}{4,101} & $-0,849$ & \multirow{6}{*}{24,608} & 4,490 & 20,934 \\
\hline 2 & 1000 & 110,67 & 70,51 & 111,52 & 67,47 & & $-0,764$ & & 4,311 & 21,165 \\
\hline 3 & 950 & 113,47 & 73,73 & 114,22 & 70,56 & & $-0,661$ & & 4,306 & 21,260 \\
\hline 4 & 900 & 113,30 & 72,03 & 113,84 & 68,93 & & $-0,477$ & & 4,311 & 21,509 \\
\hline 5 & 850 & 112,86 & 72,80 & 113,37 & 69,81 & & $-0,456$ & & 4,107 & 21,653 \\
\hline 6 & 800 & 113,37 & 72,22 & 113,80 & 68,50 & & $-0,093$ & & 3,932 & 21,663 \\
\hline
\end{tabular}

Taking Tables VIII and IX into account, figure 7 results from drying shrinkage and figure 9 results from linear shrinkage in firing for optimal blends:

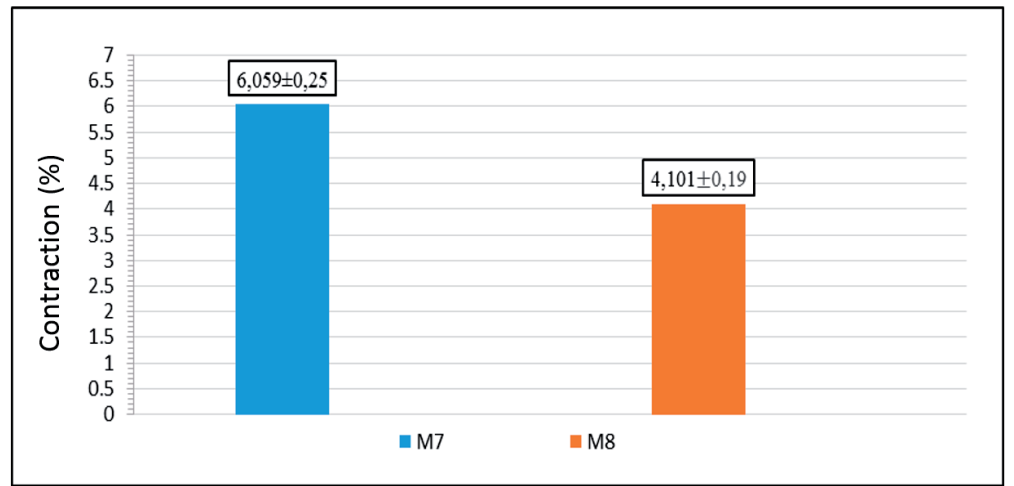

Figure 7. Shrinkage on drying of the optimum mixtures 
Normal contractions are considered for a clay conformed to those that do not exceed $10 \%$ so that there are no problems of cracks and deformations at this stage of the process. Taking into account this parameter, the two mixtures comply with the specification, so they can be used in rapid drying cycles. Subsequently, the following figure 8 was carried out in order to validate the percentages of contraction as a function of temperature. the contraction percentage at a temperature of $850^{\circ} \mathrm{C}$ is the same for the two samples with a value of $-0.456 \%$.

\section{Water Absorption}

Water absorption is one of the most important variables when evaluating a raw material composed of clay for structural use. The maximum water absorption values according to the NTC 4205

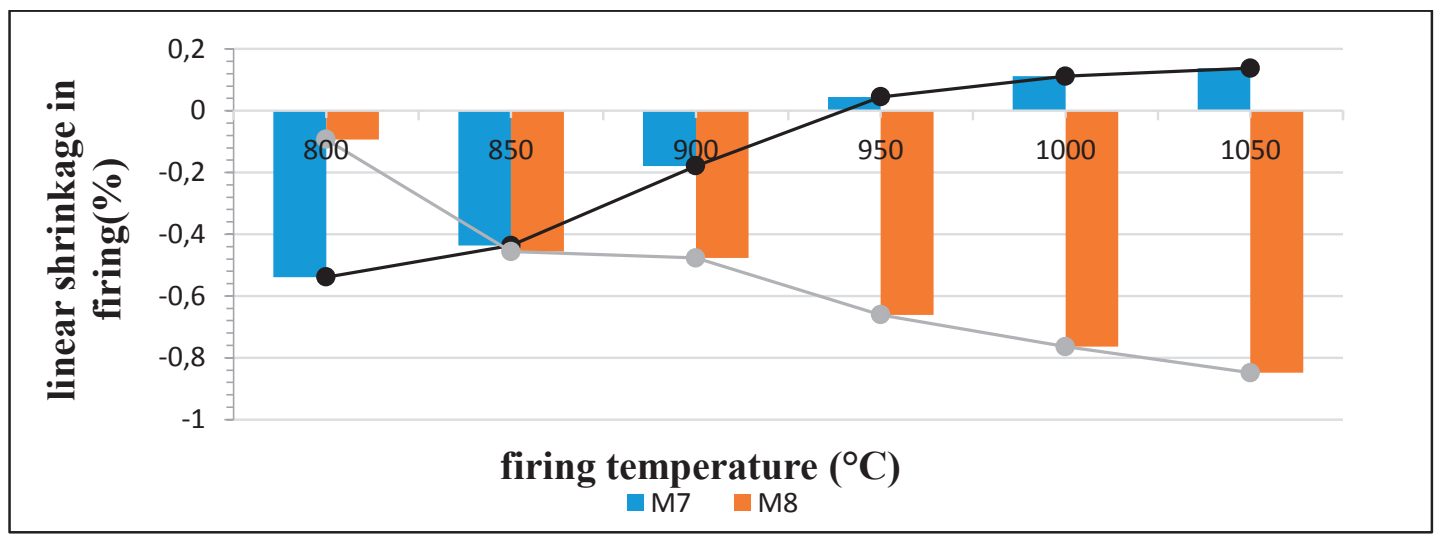

Figure 8. Linear contraction in firing and temperature

The shrinkage in firing is not higher than $2.0 \%$ at the temperatures evaluated so there should be no problems of fractures or deformations in the firing stage for the case of mixture $\mathrm{m} 7$. Together, the losses by calcination are less than $10 \%$ so there should be no problems at this stage of the process. Likewise, standard must be a maximum of $13 \%$ for indoor use and $13.5 \%$ for outdoor use.

The following figure 9 shows the percentage of water absorption as a function of the cooking temperature in the laboratory:

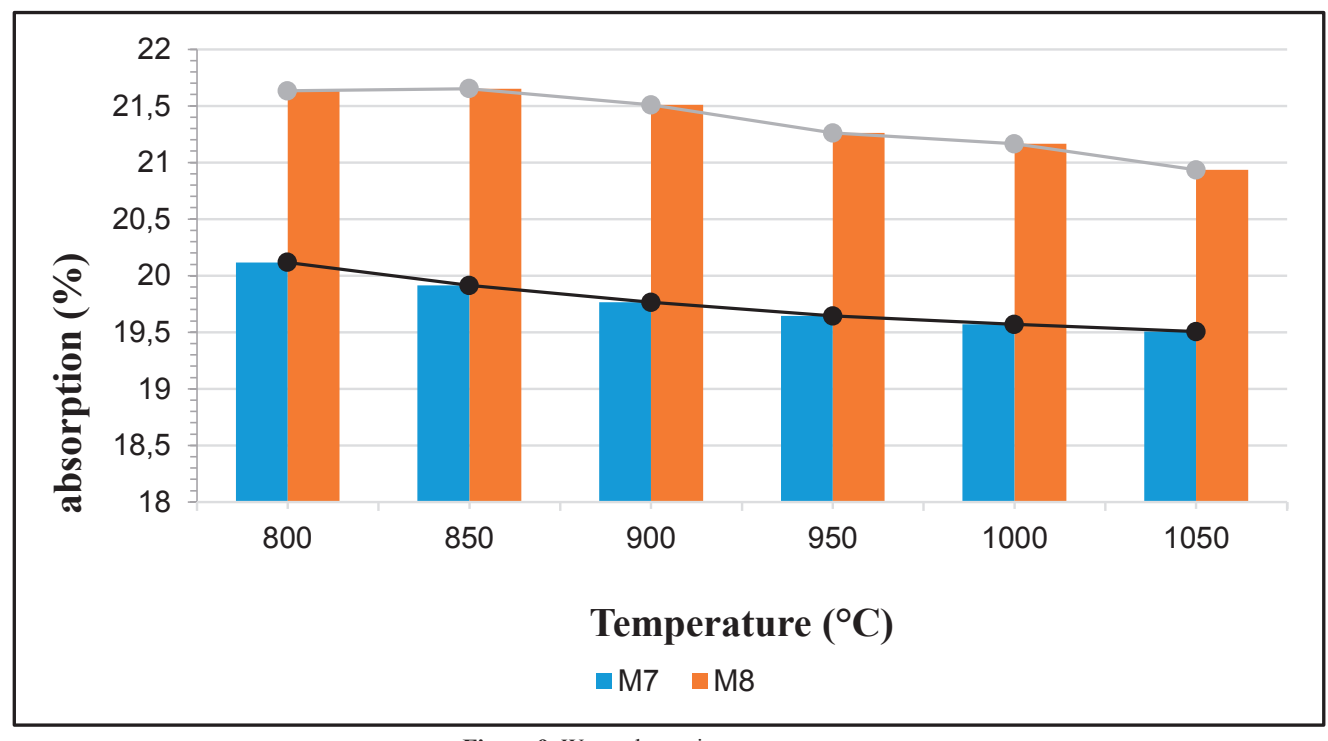

Figure 9. Water absorption vs temperature 
From figure 9, high percentages of water absorption are observed, which is due to the fact that there is an open porosity of the piece that varies depending on the temperature.

According to the values established by the NTC 4205 standard (max. 13.5\%), none of the samples meet this specification. This is due to the fact that the sand particles are large in size, where it was found that in the crushing process the ideal sand particle sizes ( $>2$ millimetres) are not obtained, so that high porosities and therefore high percentages of water absorption are obtained.

In addition, it is observed that at $950^{\circ} \mathrm{C}$ the water absorption tends to be stable as the temperature increases, with the $\mathrm{m} 7$ mixture being the most optimal, but it does not comply with the specifications of the NTC 4205 standard.

\section{Mechanical resistance to bending during firing}

This analysis allows us to know if the manufactured products comply with the minimum standards established in the national and international standards in force for masonry products for onstruction and is used as quality control in the manufactured parts. It was carried out taking into account the provisions of standard NTC 4321-4 (Figure 10) [27].

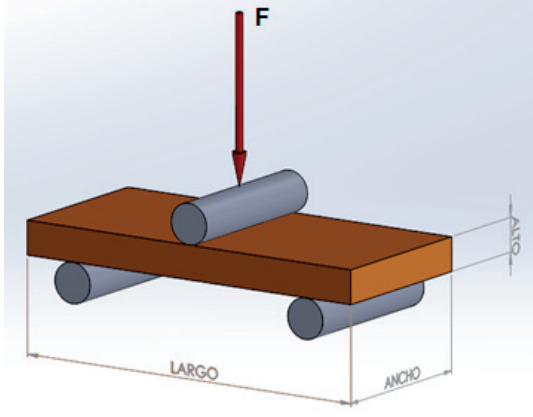

Figure 10. Mechanical resistance to bending and breaking load

The flexural strength of specimens obtained at different temperatures was then determined. The load fixed to the specimen was applied in two supports, where later the necessary conversions were made $(\mathrm{N} /$ $\mathrm{mm}^{2} \rightarrow 10,2 * \mathrm{KgF} / \mathrm{cm}^{2}$ ). The following information was obtained:

Table X. Ultimate flexion stress as a function of temperature

\begin{tabular}{|c|c|c|}
\hline \multirow{2}{*}{ Temperature } & \multicolumn{2}{|c|}{ Ultimate stress $\left(\mathbf{K g f} / \mathbf{c m}^{2}\right)$} \\
\cline { 2 - 3 } & $\mathbf{M 7}$ & M8 \\
\hline 800 & 18,36 & 12,24 \\
\hline 850 & 21,93 & 14,28 \\
\hline 900 & 24,48 & 14,28 \\
\hline 950 & 27,03 & 19,89 \\
\hline 1000 & 22,44 & 15,81 \\
\hline 1050 & 20,40 & 18,36 \\
\hline
\end{tabular}

From the previous table $\mathrm{X}$, the following figure 11 results for the two selected blends:

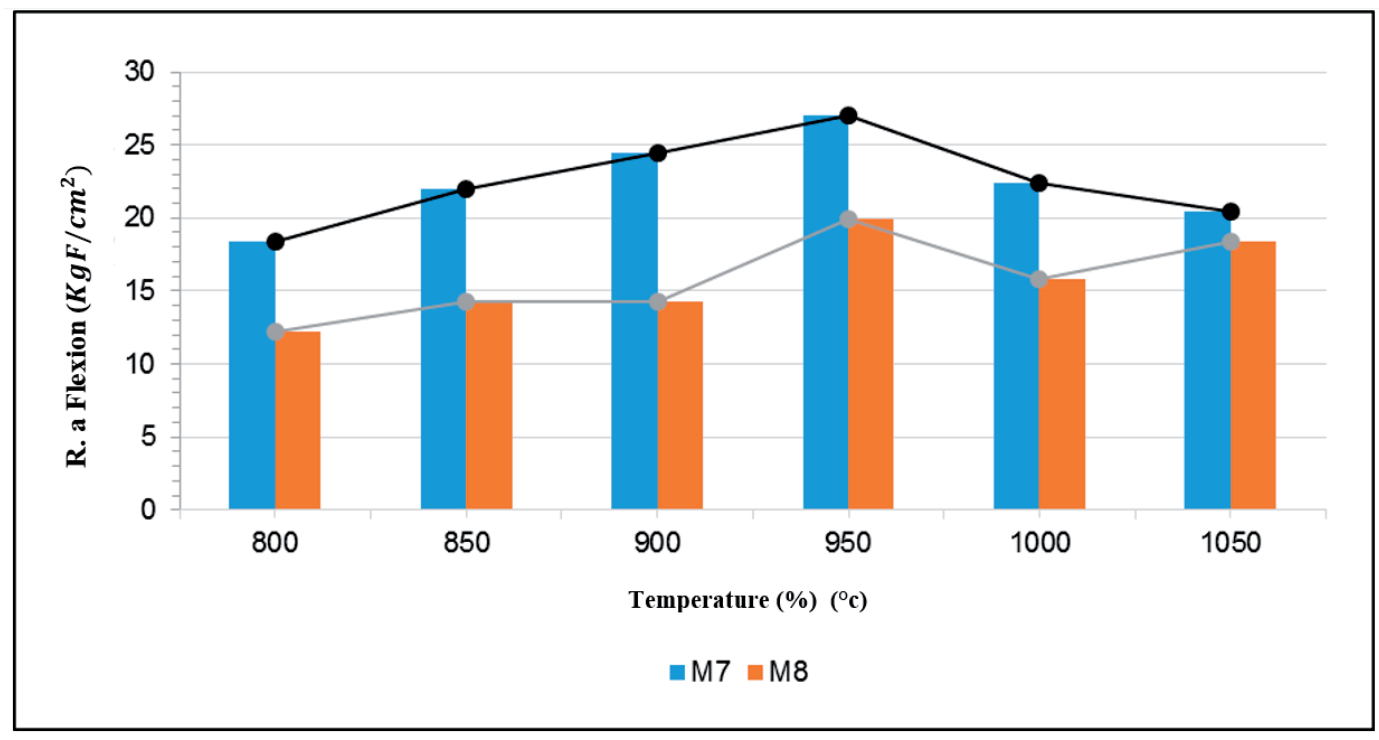

Figure 11. Temperature Vs Resistance to bending 
The results for any of the temperatures and mixtures worked are below the normal values of mechanical resistance for structural masonry products, which are between $100 \mathrm{Kg} / \mathrm{cm}^{2}\left(9.81 \mathrm{~N} / \mathrm{mm}^{2}\right)$ and $150 \mathrm{Kg} /$ $\mathrm{cm}^{2}\left(14.72 \mathrm{~N} / \mathrm{mm}^{2}\right)$ according to [28]. Figure 11 also shows that both mixtures are more resistant to $950^{\circ} \mathrm{C}$.

Likewise, the mechanical properties in ceramic materials are influenced by the porosity related to the mechanical resistance to flexion and by decreasing the porosity of the material inevitably increases and improves the characteristics of the materials (particle size).

\section{Bigot curve}

This analysis was carried out with the purpose of observing the behavior of the material in the drying stage, determining mainly the contraction speed of the sample at the different selected temperatures and relating the losses due to drying with the percentage of dry contraction of the conformed specimens [29].

The drying process was carried out in two temperatures of $60 \pm 5^{\circ} \mathrm{C}$ and $80 \pm 5^{\circ} \mathrm{C}$, from which the initial temperature of $30 \pm 5^{\circ} \mathrm{C}$ was averaged. From the data obtained from the physical ceramic analysis, the following values are obtained for the Bigot curve, taking into account the percentage of contraction and the loss of mass in relation to the temperature present in Table XI:

Table XI. Mean values of the Bigot curve for the selected samples

\begin{tabular}{|c|c|c|c|c|}
\hline \multicolumn{2}{|c|}{ Termal cycle } & \multicolumn{3}{c|}{ Average } \\
\cline { 2 - 5 } & Dry contraction & Mass losses & Contraction velocity \\
\hline Temperature ${ }^{\circ} \mathrm{C}$ & Blend & $\%$ & $\%$ & $(\% /$ Min) \\
\hline \multirow{2}{*}{ \pm 30} & $\mathrm{~m} 7$ & 0.760 & 0.445 & 0.050 \\
\cline { 2 - 5 } & $\mathrm{m} 8$ & 1.005 & 1.865 & 0.060 \\
\hline \multirow{2}{*}{ \pm 60} & $\mathrm{~m} 7$ & 0.414 & 1.036 & 0.027 \\
\cline { 2 - 5 } & $\mathrm{m} 8$ & 0.028 & 0.056 & 0.00186 \\
\hline \multirow{2}{*}{ \pm 80} & $\mathrm{~m} 7$ & 0.379 & 1.116 & 0.025 \\
\cline { 2 - 5 } & $\mathrm{m} 8$ & 0.286 & 0.712 & 0.019 \\
\hline
\end{tabular}

The results obtained in table XI for the different drying cycles show a significant variation between the two mixtures (M7 and M8) because the contraction speed decreases as the temperature increases. The curves made at different temperatures show a similar behaviour, but it can be deduced that the best behaviour is obtained at room temperature $\left( \pm 30^{\circ} \mathrm{C}\right)$. The contraction speed is lower at this temperature so you will not have a high risk of breakage during the process.

There are several variables of the productive process that intervene in the moment of the drying of the product, such as relative humidity, temperature of the environment, speed of the drying, and among the most important the speed of the contraction, due to that if this variable is not controlled in optimal ranges deformations and internal defects can be produced, which are not visible during the several stages of drying that are presented during the process of manufacture of blocks. This behavior can be validated with a thermogravimetry analysis.

\section{Conclusions}

The mixture of clays for the manufacture of bricks is currently $60 \%$ sandy clay and $40 \%$ plastic clay being this mixture one of the possible causes of poor quality of the block as for example: Cracks, poor firing, non-uniform color, among other factors that affect the finished product by an inadequate dosage [17], [30], [31].

A new mixing proposal was determined taking into account the Winkler diagram and the results obtained from the chemical, granulometric and plastic composition analyses of three samples (M1, M2 and M5) which behave like silty-clay sands, with low plasticity and high silica content, M3 and M4 samples were not used due to their low plasticity.

The results of the granulometry tests indicate that most of the samples have an index of $45 \%$ of fine sand; being of great importance for the manufacture of ceramic pastes or mixtures based on clays, because it helps to reduce the drying time and avoids the formation of cracks in the pieces. In general, the samples evaluated present high sand contents, greater than $25 \%$. The percentages of sand suitable for the manufacture of extruded ceramic products are those between $16 \%$ and $35 \%$. Considering the above, the mixtures do not need the extra addition of sand to be able to be extruded in an adequate way. In addition, it is important to control the percentages of sand is indicates that the clays need higher temperature to be able to close the pores in the firing, reason why, to 
low temperatures of firing will give high absorptions of water and low resistance in firing.

In order to formulate the optimum clay mixture, it must have an approximate composition of (58.5\% Sand - 20.1\% Silt - 21.4\% Clay), which is a central point on the region established as optimal and can be varied by $\pm 2 \%$, from which more can be derived as long as they are formulated under the percentage ranges (Sand-Silt - Clay) and leave the region of zone 2 of the Winkler diagram. In addition, the mixing percentage of the samples must ensure equilibrium between the mines, i.e. that the raw material resources are not depleted by using only one sample as a large percentage.

The mixtures studied (M7 and M8) do not show normal contractions, since those that do not exceed $2.0 \%$ at temperatures up to $970^{\circ} \mathrm{C}$ and $1050^{\circ} \mathrm{C}$ are considered optimal, not exceeding $4.0 \%$ for clays used in the manufacture of extruded products [32][34].

It can be stated that a good clay to be used in the production of masonry products those samples that work at low temperature, ie between $950^{\circ} \mathrm{C}$ and $1050^{\circ} \mathrm{C}$. In addition, they present water absorption values that comply with the standard of finished product to be produced, as established by the standard NTC 4017 and 4205.

\section{References}

[1] R. A. Muñoz, J. A. Muñoz, P. Mancilla, and J. E. Rodríguez, "Caracterización fisicoquímica de arcillas del municipio de Guapi- costa pacífica caucana (Colombiana)," Química, vol. 31, pp. 537-544, 2007.

[2] J. Barranzuela, Proceso productivo de los ladrillos de arcilla producidos en la región piura. 2014.

[3] S. A. Jácome Manzano, Evaluación termodinámica del proceso de cocción y análisis de gases en hornos a cielo abierto y Hoffman en Ocaña, Universidad Francisco de Paula Santander Ocaña: Repositorio ufpso, 2012.
[4] R.A. García-León andE.Flórez, "Determinación de la ventana del proceso productivo en la fabricación de bloques H-10 en Ocaña Norte de Santander y la región," Ingenio UFPSO, vol. 9, no. 2011-642X, pp. 35-43, 2016.

[5] R. A. García-León, R. Bolívar, and E. Flórez, "Validación de las propiedades físico-mecánicas de bloques H-10 fabricados en Ocaña Norte de Santander y la región," Ingenio UFPSO, vol. 10, no. 2011-642X, pp. 17-26, 2016.

[6] E. Velasco Sánchez, M. Sánchez Lozano, R. Peral Orts, and G. AME, Libro de artículos del XXI Congreso Nacional de Ingeniería Mecánica, Universita. Elche. España, 2016.

[7] O. Riojas Castillo and N. E. Rodríguez Montaña, "Características de hornos para productos cerámicos del Parque Minero Industrial El Mochuelo, localidad 19 de Bogotá, D.C.," ConCiencias, 2004.

[8] E. Kamseu et al., "Characterisation of porcelain compositions using two china clays from Cameroon", Ceramics International, vol. 33, no. 5, pp. 851-857, 2007.

[9] S. N. Monteiro and C. M. F. Vieira, "Influence of firing temperature on the ceramic properties of clays from Campos dos Goytacazes, Brazil", Applied Clay Science, vol. 27, no. 3-4, pp. 229234, 2004.

[10] J. A. Junkes, M. A. Carvalho, A. M. Segades, and D. Hotza, "Ceramic tile formulations from industrial waste," InterCeram: International Ceramic Review, vol. 60, no. 1, pp. 36-41, 2011.

[11] Y.Q. Martínez, “Caracterización fisicoquímica de cuarzo en el municipio de la Playa de Belén (Norte de Santander)", trabajo de fin de grado, Universidad Francisco de Paula Santander, Ocaña, 2012.

[12] M. Lassinantt, M. Romagnoli and A.F. Gualtieri, "Influence of body composition on the technological properties and mineralogy of stoneware: A DOE and mineralogical- 
microstructural study", Journal of the European Ceramic Society, vol. 31, no. 5, pp. 673-685, 2011.

[13] L. Cely Illera, "Raw materials for the ceramics industry from norte de santander. I. Mineralogical, chemical and physical characterization," Revista Facultad de Ingeniería, no. 80, pp. 31-37, 2016.

[14] M. Mora, G. López, M.A. Bengochea and P.A. López, "Boletín de la sociedad Española de Cerámica y Vidrio", Cerámica y Vidrio”, vol. 50, no. 2, pp. 99-108, 2011.

[15] J. F. Gelves and J. Sánchez, "Comportamiento de las arcillas del Área Metropolitana de Cúcuta sometidas a proceso de moldeo por extrusión.," Respuestas, vol. 14, no. 2, pp. 32-38, 2009.

[16] B. K. Ngun, H. Mohamad, K. Katsumata, K. Okada, and Z. A. Ahmad, "Using design of mixture experiments to optimize triaxial ceramic tile compositions incorporating Cambodian clays", Applied Clay Science, vol. 87, pp. 97-107, 2014.

[17] M. Coronado, A. M. Segadães, and A. Andrés, "Combining mixture design of experiments with phase diagrams in the evaluation of structural ceramics containing foundry byproducts", Applied Clay Science., vol. 101, pp. 390-400, 2014.

[18] R.R. Menezes et al., "Optimization of wastes content in ceramic tiles using statistical design of mixture experiments," Journal of the European Ceramic Society, vol. 28, no. 16, pp. 3027-3039, 2008.

[19] G. Mendoza, H, Bautista, "Diseño Experimental.," Universidad Nacional de Colombia, 2002. .

[20] C. Martínez Bencardino, Estadísticay Muestreo, ECOE. Colombia, 2012.

[21] D. C. Ortega Pérez, M. O. Bustamante Rua, D. F. Gutiérrez Rôa, and A. A. Correa Espinal, "Mixture experiments in industrial formulations
Diseño de mezclas en formulaciones industriales," DYNA, vol. 82, no. 189, pp. 149156, 2015.

[22] H. Gutiérrez Pulido and R. De La Vara Salazar, Análisis y diseño de experimentos, Mc Graw Hi. Mexico, 2008.

[23] Statgraphics, "Diseño de Experimentos Diseños de Mezclas," Biblioteca Statgraphics, 2006. [Online]. Available: https://www. statgraphics.net/tutoriales/.

[24] R. A. García-León and R. Bolívar, "Caracterización Hidrométrica de las Arcillas Utilizadas en la Fabricación de Productos Cerámicos en Ocaña , Norte de Santander," INGE CUC, vol. 13, no. 1, pp. 1-9, 2017.

[25] J. García, H. Medina and D. Núnez, "El método del hidrómetro: influencia de los tiempos de lecturas en el cálculo de la distribución del tamaño de partículas en suelos de la Habana", Cultivos Tropicales, vol. 29, no. 2, pp. 21-26, 2008.

[26] J. S. S. Román, "Diagramas triangulares," Dpto. Geología. Universidad de Salamanca. España, Salamanca., pp. 1-2, 2014.

[27] Norma-Técnica-Colombiana, "Determinación del módulo de rotura y la resistencia a la flexión en probetas cerámicas NTC 4321-4," 1997.

[28] L. Cely Illera, Comportamiento Térmico y Mecánico de una arcilla de la región de Norte de Santander. 2012.

[29] E. Espinel Blanco, T. Velásquez Pérez, and C.A. Pallares, "Physical and mechanical properties of H10 ceramic blocks and their relation to temperature during the cooking process," Prospectiva, vol. 15, no. 2, pp. 74-84, 2017.

[30] H. Gutiérrez Pulido and R. De La Vara Salazar, Análisis y diseño de experimentos., McGrawHil., vol. 1. Mexico, 2015.

[31] J. Sánchez, J. A. Orozco, and L. Peñaloza, "Evaluación de mezclas de arcillas para la 
fabricación de ladrillos refractarios que sirvan para la reconversión tecnológica de los hornos utilizados en Norte de Santander", Revista de Investigaciones, vol. 26, no. 1, pp. 57-64, 2014.

[32] R.A. García-León, E.N. Flórez-Solano y Y. Medina-Cárdenas, "Caracterización física de las arcillas utilizadas en la fabricación de productos de mampostería para la construcción en Ocaña Norte de Santander", Espacios, vol. 39, no. 53, pp. 1- 6, 2008.

[33] R.A. García-León, E.N. Flórez-Solano and C.H. Acevedo-Peñaloza, "Clay surface characteristics using atomic force microscopy", Revista Facultad de Ingeniería, no. 87, pp. 23-34, 2018. doi: 10.17533/udea.redin. n87a04

[34] R.A. García-León, E.N. Flórez-Solano y M.M. Rodríguez-Castilla, "Diseño de mezclas para la fabricación de productos de mampostería en la industria cerámica", Revista Politécnica, vol. 14, no. 26, pp. 19-28, 2018. 